\title{
Relative Short-Term Persistence and Absolute Short- Term Persistence of Islamic Mutual Funds in Indonesia
}

\author{
Zaenal Arifin ${ }^{1}$, Sri Mulyati ${ }^{2}$ \\ Faculty of Economics and Business, Universitas Islam Indonesia, Indonesia \\ ${ }^{1}$ zaenalarifin.feduii.ac.id \\ ${ }^{2}$ mulyati@uii.ac.id
}

\begin{abstract}
The development of Islamic mutual funds in Indonesia is quite rapid, but unfortunately there is currently no islamic/sharia mutual fund investment model that helps investors choose the right sharia mutual funds. Therefore, we conduct a study to find investment model of Islamic mutual fund in Indonesia. The first step in creating a mutual fund investment model is to test the persistence level of Islamic mutual fund performance. In this study, we tested the relative short-term persistence and absolute short-term persistence. Relative persistence is done by looking at whether the existing funds in the top five in a given month remain in the top five in the following months. Absolute persistence is tested with the Autoregressive Moving Average (ARMA) time series model. By using Sharia mutual fund samples from 2010 to 2016 this study found the following three points. First, stock mutual funds and mixed mutual funds have relatively high relative-short-termpersistence in the early period of the research year $(2010-2012)$ but then decline thereafter but fixed income mutual funds have an up-and-down pattern of persistence. Second, in general, stock mutual funds have the highest relative-short-term -persistence, followed by mixed mutual funds, and fixed income mutual funds. Third, judging from absolute-short-term -persistence, only fixed income mutual funds have persistent performance. The results of this study are expected to contribute to the study of Islamic investment, especially in order to find a model of investing in Islamic mutual funds.
\end{abstract}

Keywords — sharia mutual funds, short-term performance, persistence, relative performance persistence, absolute performance persistence

\section{INTRODUCTION}

Mutual funds are professionally managed financial investment products. This product is suitable to be an option for investors who do not have much knowledge about the capital market or investors who do not have time to observe the development of the capital market. In Indonesia, there are mutual funds in accordance with sharia. Sharia mutual funds in Indonesia has existed since 1997. This is marked by the launch of Danareksa Syariah on July 3, 1997 by PT. Danareksa Investment Management. The development of
Islamic mutual funds in the last twelve years is quite rapid. The growth of Islamic mutual funds is higher than that of conventional mutual funds. The proportion of Islamic mutual funds to the total number of mutual funds is always increasing from year to year. It is also found in the proportion of Net Asset Value (NAV) of sharia mutual funds

Why Sharia Mutual Fund is growing rapidly in Indonesia? The rapid growth of this mutual fund could be because mutual funds can manage large enough funds to diversify their investments well, which is difficult for individual investors with limited funds. Because the funds are large, then mutual funds can perform block sale transactions that have lower transaction costs. The development of Islamic mutual funds in Indonesia can also be due to the performance of Islamic mutual funds over the years. If the proportion of NAV of Islamic mutual funds has a tendency to increase, it can be interpreted that Islamic mutual funds generally provide higher returns than conventional mutual funds. However, a number of previous studies that compare the performance of Islamic mutual funds and conventional funds do not support it. Reference [5] found that in the 2008 crisis period, conventional mutual funds performed better than market performance while Islamic mutual funds were lower than market performance. Meanwhile [3] found that conventional funds are better than Islamic mutual funds for stocks and mixed mutual funds, while for fixed income mutual funds Sharia mutual fund performance is better. Only reference [8] found that the performance of Islamic mutual funds is better than the performance of conventional mutual funds. From a number of studies it is seen 
that the performance of Islamic mutual funds is not always better than conventional mutual funds.

Comparison of the performance of Islamic mutual funds and conventional funds in a number of countries also vary. In Saudi Arabia, [2] found no difference in performance between sharia and conventional mutual funds. In Malaysia, [11] found that Sharia mutual funds perform better than conventional mutual funds in bearish periods and in bullish periods sometimes sharia mutual funds are better but sometimes better conventional mutual funds. In international mutual funds samples, [4], [1] found no difference between the performance of sharia and conventional mutual funds. While [8] found that the performance of Islamic mutual funds is lower than conventional mutual funds. While sharia mutual funds perform better than their international counterparts.

If the performance of sharia mutual funds cannot be used as an advantage then another argument is needed to select it. For Muslim investors, the reason for halalness can be used as a reference. Even if the performance or return received is lower than the conventional they will still choose the sharia. This argument also applies to investors who choose shares of companies with social concerns. Although the stock return in the socially responsible investment (SRI) index is not superior to the company's stock in general, even according to [9] findings the return is lower, stocks in the SRI index are still growing. Another reason is to diversify investments because there are superior Islamic Shari'ah findings at bearish market conditions, such as [11]. If the reason for choosing a sharia mutual fund because of halalness or for diversification of investment, then the problem is how to choose the best of existing Islamic mutual funds.

Reference [7] argues that the rapid development of mutual funds in America because of the persistence of mutual funds performance. If mutual funds have persistent performance then investors will be easier in choosing mutual funds. If the performance of mutual funds is persistent, then investors simply choose mutual funds that perform well in the previous period and will get a good return also in the future. Reference [7] found a persistence of mutual fund performance in the period 1985-1994 in the United States. Meanwhile
[7] also found persistence performance in the period 1974-1984. Conventional mutual fund performance persistence test in Indonesia has been done by a number of researchers. Reference [3] using data from 2006 to 2011 found no mutual funds with persistent performance for 5 consecutive years but found persistence in the shorter term when using Jensen index and Sharpe index but never persistent when using Treynor index. Meanwhile, [5] found a persistence of mutual fund performance for the period of 2008-2012. Thus, whether or not the persistence of performance of mutual funds in Indonesia is not conclusive

Until now we have not found any research on the persistence of Islamic mutual funds in Indonesia. At the international level, the study of the persistence of Islamic mutual funds is also limited as stated by [10] when reviewing the performance of Islamic mutual funds. Using Sharia mutual fund data from the Dow Jones Islamic Index from 1999 to 2011, [10] found no persistence of Sharia mutual fund performance. But their persistence test is relatively limited because it only compares the recession and expansion periods according to the business cycle of the company.

This research will make investment model of sharia mutual fund in Indonesia. The number and growth of Islamic mutual funds justifies the importance of the Islamic mutual fund investment model. Sharia mutual fund investment model will be relatively easy to make if the performance of Islamic mutual funds in Indonesia is persistent. Therefore, this research begins by testing the persistence of Islamic mutual funds in Indonesia. Persistence testing can be done for the long term or short term. This study chose to test the short-term persistence of both absolute and relative persistence.

An easy way to comply with the conference paper formatting requirements is to use this document as a template and simply type your text into it. Sharia mutual funds are mutual funds that invest their funds into securities in accordance with Islamic law. The types of Islamic mutual funds offered are the same as those offered by conventional mutual funds including stock mutual funds, fixed income, mixed, money markets, protected, and indexes. However, not all securities may be included in the portfolio of Islamic mutual 
funds. Sharia equity mutual funds only include Sharia stocks listed in the List of Sharia Securities in Indonesia Stock Exchange as an option. Sharia fixed income mutual funds only include sukuk or sharia bonds as an option. While money market mutual funds only include money market products from sharia banking.

In addition to the choice of securities, Islamic mutual fund companies also have a Sharia supervisory board. To ensure that securities included in the portfolio are in accordance with the sharia, Sharia mutual fund investment options should be screened and approved by the Sharia Supervisory Board. Shari'a regulatory and supervisory rules are binding for mutual fund companies and investment managers will be assessed by the Sharia supervisory board periodically.

The role of Sharia supervisory board may differ from one mutual fund to another. In addition to the role of endorsement, the sharia supervisory board also has a number of other roles. Among others are; studying prospectus, constitutional documents and each major agreement; advise managers regarding compliance with sharia; as well as preparing annual sharia audits and issuing reports to investors.

The performance of mutual funds is generally measured by the development of Net Asset Value (NAV). As with stocks, if we want to compare the performance of mutual funds with each other, then NAV needs to be expressed in the form of returns within a certain period. Investment performance should not only pay attention to the return but also the risks. Measures of mutual fund performance that consider returns and risks include Sharpe Measure, Treynor Measure, and Jensen Measure. The latest measures have used a number of risk factors to eliminate the effect of these factors in the performance of mutual funds. Thus, performance change is entirely seen only from the ability of investment managers in managing funds. Reference [10], for example, include four factors: market premium, size factor, value factor, and momentum factor as a mutual fund performance controller.

Research on the performance of Islamic mutual funds generally compare the performance of Islamic mutual funds with a benchmark. The first benchmark to be used as a benchmark is market performance. Market performance refers to Islamic stock indexes such as the Jakarta Islamic Index (JII) and the Dow Jones Islamic Market Index (DJIM). For example, compared the performance of Islamic mutual funds with market performance during the financial crisis of 2008 and found that the performance of Islamic mutual funds at that time was lower than the market performance. At a global level, Islamic mutual funds perform better than their international counterparts.

The most widely used comparator in Islamic mutual fund research is conventional mutual funds. The comparison results are quite diverse. In Indonesia, mutual funds are better for stocks and mixes, but Islamic mutual funds are better for this type of fixed income, and sharia mutual funds better performance and no difference in performance between sharia and conventional mutual funds. In Malaysia, [11] found that Sharia mutual funds performed better than conventional mutual funds in bearish periods but in bullish periods sometimes sharia mutual funds are better but sometimes better conventional mutual funds. At the international level, [4], [1] found no difference between the performance of sharia and conventional mutual funds. While [8] found that the performance of Islamic mutual funds is lower than conventional mutual funds.

Some investors choose to invest in mutual funds because they do not have the ability or do not have enough time to invest directly into securities. Another reason is because mutual funds are managed by investment managers who do have expertise in investing in securities. However, the capability of investment managers in each mutual fund company is of course different and this will have an impact on the performance of mutual funds. If the performance of each mutual fund is different, what is the strategy for choosing Islamic mutual fund?

The basic strategy of choosing a mutual fund, as with investments in general, is tailored to the risk profile of the investor. Investors who have a risk profile tend to choose the security of funds then the choice of mutual funds are fixed income funds, money market or protected. If the risk profile is moderate, they can choose a mixed mutual fund or index. If investors have risk profiles tend to like 
risk then they can choose stock mutual funds. This is the strategy of choosing a mutual fund based on the type of mutual fund. After determining the type of mutual fund then the investor must decide which mutual fund products should be selected.

The most frequent assessment of mutual fund selection strategy is the assessment of mutual fund performance persistence. If the performance of mutual funds is persistent, then the strategy of choosing a mutual fund is based on its performance in previous periods. Mutual funds selected are mutual funds that in previous periods perform best. Reference [7] argues that this performance persistence is what causes the rapid growth of mutual funds in America. He found the persistence of mutual fund performance in the period 1985 1994 in the United States. Meanwhile [6] also found persistence performance in the period 19741984.

Mutual fund performance persistence test in Indonesia has been done by a number of researchers. Reference [3] using data from 2006 to 2011 found no mutual funds that performed persistently for 5 consecutive years but found persistence in the shorter term when using the Jensen and Sharpe indices but never persistent when using the Treynor index. Meanwhile, [5] found a persistence of mutual fund performance for the period of 20082012. Thus, whether or not the persistence of performance of mutual funds in Indonesia is not conclusive.

The persistence test of Islamic mutual fund performance as well as the strategy of Sharia mutual fund selection is still not done much by the researcher. The authors only found the results of research by [10]. Using Sharia mutual fund data from the Dow Jones Islamic Index from 1999 to 2011, [10] no persistence of Sharia mutual fund performance. But their persistence test is relatively limited because it only compares the recession and expansion periods according to the business cycle of the company.

\section{METHODS}

The population of this research is sharia mutual fund in Indonesia. The study sample is all sharia mutual funds offered from 2010 until 2016. Relative short-run persistency test is done with the following steps. First, rank the performance of each type of sharia mutual fund each month based on its performance. The types of mutual funds analyzed are stock mutual funds, fixed income mutual funds, and mixed mutual funds. Second, take the top five mutual funds on each type of mutual fund in each month. Third, analyze persistence by seeing if the best five-month funds remain the best five in the following months. The absolute short-term persistency test is performed using an autoregressive moving average (ARMA) model. Performance of a mutual fund is persistent if the AR coefficient is significant positive.

\section{RESULTS}

A. Performance of Sharia Mutual Funds in Indonesia

Investors can monitor the progress of funds invested in mutual funds through Net Asset Value (NAV) information announced every day. By comparing NAV when buying with NAV at the moment, investors can calculate the return of mutual funds. Table I below informs the average monthly return of funds during 2010 - 2016.

TABLE I

AVERAGE MONTHLY RETURN of MUTUAL FUND 2010-2016

\begin{tabular}{|l|c|c|c|}
\hline \multirow{2}{*}{ Year } & \multicolumn{3}{|c|}{ Average Monthly Return (\%) } \\
\cline { 2 - 4 } & $\begin{array}{c}\text { Stock } \\
\text { Mutual } \\
\text { Funds }\end{array}$ & $\begin{array}{c}\text { Fixed } \\
\text { Income } \\
\text { Mutual } \\
\text { Funds }\end{array}$ & $\begin{array}{c}\text { Mixed Mutual } \\
\text { Funds }\end{array}$ \\
\hline 2010 & 2.467857 & 0.859802 & 1.816885 \\
\hline 2011 & 0.054167 & 1.341429 & 0.27369 \\
\hline 2012 & 0.703438 & 0.651548 & 0.598512 \\
\hline 2013 & 0.277302 & -0.02286 & 0.244529 \\
\hline 2014 & 2.216374 & 0.604643 & 1.693546 \\
\hline 2015 & -1.28472 & 0.171079 & -0.76918 \\
\hline 2016 & 1.936961 & 0.544019 & 1.090433 \\
\hline Mean & 0.910196 & 0.592809 & 0.706916 \\
\hline SD & 1.263805 & 0.413105 & 0.840464 \\
\hline
\end{tabular}

From Table I above shows that stock mutual funds have the highest average return, followed by mixed mutual funds, and the lowest is fixed income mutual funds. This result is in accordance with the investment rule that the higher the risk of an investment the higher the return. Shares are 
securities with a higher risk than bonds. While mixed mutual funds consist of stocks and bonds so the risks are in the middle. The high risk of equity funds is also supported by empirical facts where the standard deviation of stock funds is also the largest, followed by mixed mutual funds, and the lowest standard deviation is fixed income mutual funds. Although in general, stock mutual funds provide the highest return, but this is not always the case every year. From the table above, it can be seen that in 2011 and 2015, stock mutual funds earned the lowest returns and fixed income mutual funds earned the highest returns. The findings in 2015 may be due in that year the stock market conditions are declining so that both equity and mixed mutual funds returns are negative. But for the low return of stock mutual funds in 2011, the author has not been able to analyze the cause.

\section{IV.DISCUSSION}

The short-term relative persistence test is done by looking at whether the best five-month fund remains within the best five in the following months. Table II below is a summary of the relative persistence levels of stock fund performance for the next one to six months.

TABLE II

SUMMARY of SHORT TERM RELATIVE PERSISTENCE TEST RESULTS for STOCK MUTUAL FUNDS

\begin{tabular}{|l|r|r|r|r|r|r|}
\hline \multicolumn{7}{|c|}{ Persistence Level After } \\
\hline \multirow{2}{*}{ Year } & \multicolumn{7}{|c|}{ Months } \\
\cline { 2 - 8 } & \multicolumn{1}{|c|}{$\mathbf{1}$} & \multicolumn{1}{c|}{$\mathbf{2}$} & \multicolumn{1}{c|}{$\mathbf{3}$} & \multicolumn{1}{c|}{$\mathbf{4}$} & \multicolumn{1}{c|}{$\mathbf{5}$} & \multicolumn{1}{c|}{$\mathbf{6}$} \\
\hline 2010 & 0.85 & 0.8 & 0.85 & 0.85 & 0.8 & 0.7 \\
\hline 2011 & 0.8 & 0.7 & 0.7 & 0.7 & 0.65 & 0.75 \\
\hline 2012 & 0.8 & 0.75 & 0.85 & 0.8 & 0.7 & 0.7 \\
\hline 2013 & 0.5 & 0.45 & 0.5 & 0.3 & 0.3 & 0.3 \\
\hline 2014 & 0.5 & 0.35 & 0.35 & 0.35 & 0.3 & 0.35 \\
\hline 2015 & 0.4 & 0.15 & 0.25 & 0.35 & 0.25 & 0.1 \\
\hline 2016 & 0.3 & 0.15 & 0.3 & 0.35 & 0.2 & 0.25 \\
\hline
\end{tabular}

From the first row of Table II above it appears that in 2010, the performance of stock mutual funds has a fairly high persistence. The best five-month fund (in this study consists of January to April), $85 \%$ of which are still in the top five in the next month. For the next 2 months persistent period is $80 \%, 3$ and 4 months later persistence rate rose again to $85 \%$, next 5 months persistence rate is $80 \%$, and 6 months later still 70\%. In 2011, persistence levels were still high despite a slight weakening. In 2012, persistence levels increased again as of 2010. However, persistence declined in 2013 and subsequent years and the lowest persistence rate occurred in 2016.

Table III below is a summary of the persistence level of fixed income mutual fund performance for the next one to six months.

TABLE III

SUMMARY of SHORT TERM RELATIVE PERSISTENCE TEST RESULTS for FIXED INCOME MUTUAL FUNDS

\begin{tabular}{|c|c|c|c|c|c|c|}
\hline & \multicolumn{6}{|c|}{ Persistence Level After } \\
\hline \multirow{2}{*}{ Year } & \multicolumn{6}{|c|}{ Months } \\
\hline & 1 & 2 & 3 & 4 & 5 & 6 \\
\hline 2011 & 0.625 & 0.5 & 0.5 & 0.438 & 0.5 & 0.563 \\
\hline 2012 & 0.5 & 0.563 & 0.625 & 0.563 & 0.5 & 0.563 \\
\hline 2013 & 0.438 & 0.625 & 0.625 & 0.5 & 0.438 & 0.438 \\
\hline 2014 & 0.625 & 0.625 & 0.563 & 0.563 & 0.75 & 0.5 \\
\hline 2015 & 0.625 & 0.625 & 0.5 & 0.438 & 0.563 & 0.625 \\
\hline 2016 & 0.375 & 0.375 & 0.813 & 0.563 & 0.5 & 0.438 \\
\hline
\end{tabular}

From Table III above it appears that in general the persistence level of fixed income mutual funds is lower than the persistence level of stock funds. In the first month, the highest persistence rate was only $62.5 \%$. The pattern of inter-year persistence found in stock funds is not found in fixed income mutual funds. Indeed there is a decrease in persistence in 2012 and 2013 but then rise again in 2014 and 2015 before then down again in 2016. In 2016, the persistence rate is the lowest.

Table IV below summarizes the persistence rate of mixed mutual fund performance for the next one to six months. 
TABLE IV

SUMMARY of SHORT TERM RELATIVE PERSISTENCE TEST RESULTS for MIXED MUTUAL FUNDS

\begin{tabular}{|l|r|r|r|r|r|r|}
\hline & \multicolumn{7}{|c|}{ Persistence Level After } \\
\hline \multicolumn{1}{|c|}{ Year } & $1 \mathrm{mth}$ & Year & $1 \mathrm{mth}$ & Year & $1 \mathrm{mth}$ & Year \\
\hline 2010 & 0.7 & 0.8 & 0.8 & 0.7 & 0.8 & 0.7 \\
\hline 2011 & 0.75 & 0.65 & 0.65 & 0.65 & 0.6 & 0.75 \\
\hline 2012 & 1 & 1 & 0.9 & 0.8 & 0.7 & 0.65 \\
\hline 2013 & 0.7 & 0.55 & 0.55 & 0.35 & 0.3 & 0.3 \\
\hline 2014 & 0.4 & 0.35 & 0.25 & 0.4 & 0.45 & 0.45 \\
\hline 2015 & 0.3 & 0.25 & 0.3 & 0.25 & 0.45 & 0.35 \\
\hline 2016 & 0.2 & 0.2 & 0.35 & 0.35 & 0.35 & 0.2 \\
\hline
\end{tabular}

From Table IV above it appears that mixed mutual funds have an annual persistence pattern similar to stock funds. Like stock mutual funds, mixed mutual funds have high persistence at the beginning but then persistence levels fall in the following years. If stock mutual funds start falling from 2013, mixed mutual funds begin to fall in 2014. In addition, the mixed mutual fund's persistence rate is generally lower than stock mutual funds, although in 2012 the mixed mutual funds in the first two months were perfectly $100 \%$ persistent. As with the other two types of mutual funds, the level of persistence of mixed funds is at its lowest level in 2016.

The persistence test by looking at whether the best-performing mutual fund remains at the top 5 in subsequent periods is called a relative persistency test. In addition to the relative persistency test, there is also an absolute persistence test by using time series autoregressive moving average (ARMA) analysis or similar models. The test results used here only from the autoregressive side and the summary of the results are in Table $\mathrm{V}$ below.

TABLE V

SUMMARY of AUTOREGRESSIVE TEST RESULTS from MONTHLY MUTUAL FUND RETURNS

\begin{tabular}{|r|r|r|r|r|r|r|}
\hline & \multicolumn{7}{|c|}{ Persistence Level After } \\
\hline Year & 1 month & Year & 1 month & Year & 1 month & Year \\
\hline 2010 & 0.7 & 0.8 & 0.8 & 0.7 & 0.8 & 0.7 \\
\hline 2011 & 0.75 & 0.65 & 0.65 & 0.65 & 0.6 & 0.75 \\
\hline 2012 & 1 & 1 & 0.9 & 0.8 & 0.7 & 0.65 \\
\hline 2013 & 0.7 & 0.55 & 0.55 & 0.35 & 0.3 & 0.3 \\
\hline 2014 & 0.4 & 0.35 & 0.25 & 0.4 & 0.45 & 0.45 \\
\hline 2015 & 0.3 & 0.25 & 0.3 & 0.25 & 0.45 & 0.35 \\
\hline 2016 & 0.2 & 0.2 & 0.35 & 0.35 & 0.35 & 0.2 \\
\hline
\end{tabular}

Absolute persistent mutual fund performance is characterized by a significant positive autogression coefficient. If the coefficient is positively significant meaning good performance in a period will be followed by good performance also in the future. From the table above it appears that only fixed income mutual funds are performance persistent, even the persistence level is perfect. There are 7 mutual fund samples analyzed and all of them have significant positive autoregression coefficients. Stock mutual funds have a sample of 14 mutual funds and none of them are significant persistent. While mixed mutual funds have samples of 11 mutual funds and only one (9\%) are persistent.

\section{CONCLUSIONS}

Using sharia mutual funds in Indonesia from 2010 to 2016, this study finds the following points. First, the short-term persistence of stock and mix mutual funds is quite high at the beginning of the research year (2010-2012) but then declines thereafter but fixed income mutual funds have a pattern of persistence up and down. Second, in general, stock mutual funds have the highest shortterm persistence, followed by mixed mutual funds, and fixed income mutual funds. Third, judging from the absolute short-term persistence, only fixed income mutual funds whose performance is persistent and even of perfect persistence. The results of this study are expected to contribute to the study of Islamic investment, especially in order to find a model of investing in Islamic mutual funds. The existence of sharia mutual fund investment model will help investors in choosing the right sharia mutual fund.

\section{ACKNOWLEDGMENT}

The authors would like to thank the Ministry of Research and Technology of Higher Education who has funded this research project. The authors also thank our colleagues in the Management Department and the Master of Management Program of Universitas Islam Indonesia who have provided input for the perfection of this article.

\section{REFERENCES}

[1] Abderrezak, F. (2008), The Performance of Islamic Equity Funds: A Comparison to Convensional, Islamic and Ethical Benchmarks, Thesis, Department of Finance, University of Maastricht. 
[2] Dabbeeru, R. (2006), Performance Analysis of Mutual Funds in Saudi Arabia, SRRN eLibrary. http://ssrn.com/paper=921523.

[3] Dwianggoro, A., S P Anantadjaya, dan M Sibarani, (2012), Reksadana Saham Di Indonesia: Analisa Persistensi Periode April 2006 - Maret 2011, Finance \& Accounting Journal, 1 (2) September, pp 69 - 83.

[4] Elfakhani, S., M K Hassan, dan Y Sidani (2005), Comparative Performance of Islamic Versus Secular Mutual Funds, Proceeding Economic Research Forum Conference, 19-21 Mei, Kairo, Mesir

[5] Elvani, V dan N Linawati, (2013), Uji Konsistensi Kinerja Reksadana Saham di Bursa Efek Indonesia Periode 2008-2012, FINESTA, 1(2), pp 130-135..

[6] Grinblatt M. dan S. Titman, (1992), The Persistence of Mutual Fund Performance, The Journal of Finance, XLVII (5), 1977-1984.
[7] Gruber, J. Martin, (1996), Another Puzzle: the Growth in Actively Managed Mutual Fund, The Journal of Finance, LI (3), 783-810.

[8] Hayat, R dan R. Kraeussl (2012), Risk and Return Characteristics of Islamic Equity Funds, Emerging Market Review, 12(2), pp 189-203.

[9] Jones, S. S, van der Laan. G, Frost, \& J, Loftus. (2008). The Investment Performance of Socially Responsible Investment Fund in Australia. Journal of Business Ethics, 80, 181-203.

[10] Khamlichi, A., M. Arouri, dan F Teulon, (2014), Persistence of Performance Using The Four-Factor Pricing Model: Evidence from Dow Jones Islamic Index, The Journal of Applied Business Research, 30 (3), 917- 926.

[11] Mansor, F dan M. I. Bhatti (2011), The Islamic Mutual Fund Performance: New Evidence on Market Timing and Stock Selectivity, Proceeding 